\title{
A model-based assessment of the potential role of irrigated cropland for biogas production in Europe
}

\author{
R. Schaldach, M. Flörke, and D. Lapola \\ Center for Environmental Systems research, University Kassel, Germany \\ Received: 14 January 2009 - Revised: 23 March 2009 - Accepted: 28 April 2009 - Published: 12 August 2009
}

\begin{abstract}
For the European Union, the increasing use of renewable energy sources is an important instrument to reduce its greenhouse gas emissions and to achieve greater independency from energy imports. Here, agriculture has the chance to become an important contributor by the cultivation of bioenergy crops. In this paper, the potential role of irrigated cropland for the cultivation of silage maize for biogas production is analyzed on the European level. A methodology is developed to identify suitable locations for maize cultivation and to evaluate their performance in respect of the amount of irrigation water and land needed for energy production. For this purpose, GIS analysis techniques are combined with simulation results from the process-based vegetation model LPJmL for maize yields and irrigation water requirements. The generated information can serve as input for the development of European-scale bio-energy policies and for further analysis of the water footprint and energy balance of bioenergy systems.
\end{abstract}

\section{Introduction}

Two important objectives of increasing the use of renewable energy sources in the European Union (EU) are the reduction of greenhouse gas emissions and greater independence from fossil fuel imports. According to the Biomass Action Plan (EC, 2005), if the EU made full use of its agricultural potential, it would more than double its use of biomass for energy production by 2010 from 69 million tons of oil equivalent (MtOE) in 2003 to about $150 \mathrm{MtOE}$. In this case, the European agriculture has the chance to become a major contributor to bio-energy production with bio-energy cropping being a substantial source of income to farmers. Apart from

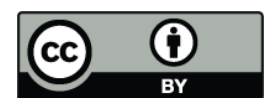

Correspondence to: R. Schaldach (schaldach@usf.uni-kassel.de) these positive effects, agricultural management is already intensive in most European regions and a further increase of biomass production could cause additional pressures on natural resources such as biodiversity, soil and water (EEA, 2006). Furthermore, Searchinger et al. (2008) and Fargione et al. (2008) point out that the conversion of grassland or forest to cropland bears the risk of degradation of soil carbon pools, reducing the carbon-saving effect of bio-energy usage considerably. Taking into account these negative environmental effects and in order to avoid competition for land needed for food production, the recent assessments of bioenergy potentials assume that bio-energy crops will be grown on agricultural land that is taken out of production due to its low fertility or profitability (e.g. EEA, 2006; Hoogwijk et al., 2005).

In this paper, we take a different perspective and argue that two important prerequisites for the successful implementation of bio-energy cropping are (1) yield levels that are high enough for being competitive in energy markets and (2) efforts to minimize yield losses under climatic stress conditions during the vegetation period in order to sustain a high reliability of energy production. Based on these assumptions, we develop and apply a model-based methodology to conduct a spatially explicit assessment of the potential role of irrigated cropland for bio-energy production in Europe. Our analysis focuses on silage maize as substrate for biogas production. Options for the use of biogas include combined heat and power generation and fuel for the transportation sector. The major reason for concentrating on this bio-energy pathway is its high greenhouse gas reduction potential compared to alternative pathways, such as bio-diesel from rapeseed or bio-ethanol from corn maize (Thyø and Wenzel, 2007). Furthermore, biogas production is a flexible technology which is not bound to a specific type of substrate. This, for instance, allows using silage maize together with harvest residues from other types of crops and grasses. 


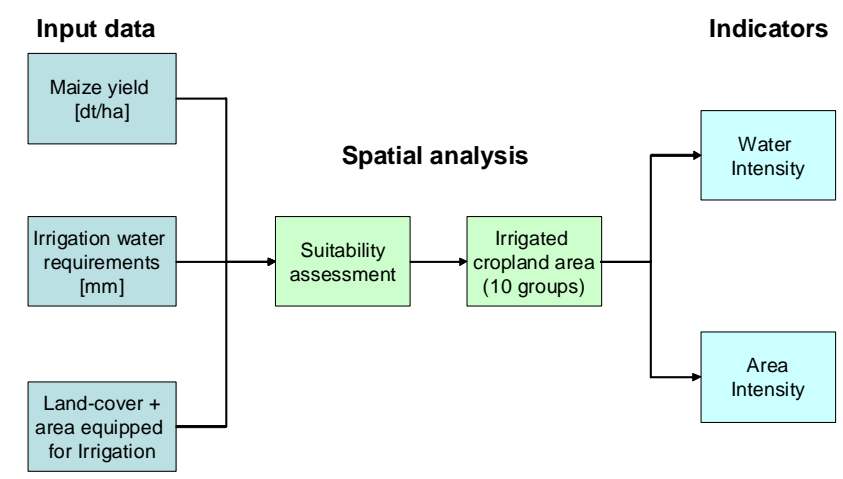

Fig. 1. Workflow of the study.

\section{Materials and methods}

\subsection{Workflow and input data}

The assessment is carried out on a uniform grid with a cell size of 5 arc-min. Study area is the territory of the EU27 plus the non-member countries Croatia, Serbia and Albania. The analysis combines a Geographic Information System (GIS), methods from decision theory and the output from a processbased vegetation model to perform a spatially explicit analysis. Fig. 1 illustrates the workflow of the assessment.

The spatial input data is prepared using the GIS software package ArcGIS 9.2. Basis for the analysis is the CORINE 2000 (EEA, 2007) land-cover database for EUmember countries and the global crop map developed by Heistermann (2006) for the non-member countries. Both grid maps are combined to identify the cropland area within the study region. Then, the Global Map of Irrigated Area GMIA (Siebert et al., 2007) is used to derive for each 5 arc-min cropland cell the fraction of area equipped for irrigation. The analysis considers only cropland cells with an area equipped for irrigation greater zero. In the following, we refer to this set of cells as irrigated cropland. Maize yields and irrigation water requirements (iwr) are calculated by the LPJmL model (Sitch et al., 2003; Bondeau et al., 2007). The procedure for generating this data is described in greater detail in the next section. Model output is produced on a 30 arc-min grid. With GIS grid operations the model output is assigned to the 5 arc-min irrigated cropland cells located within each 30 arc-min cell.

Using this input data, a grid-based multi-criteria analysis is conducted to determine each irrigated cropland cell's suitability for the cultivation of maize (Sect. 2.3). In the following step, the cells are ranked according to their suitability value. Based on this ranking, the area of irrigated cropland is subdivided into 10 groups (deciles), each including $10 \%$ of the total area. Finally, indicators are calculated to evaluate the performance of each group in respect of their requirements of irrigation water and area for energy production.

\subsection{Simulation of crop yields and irrigation water re- quirements}

The LPJmL model, a more comprehensive version of the LPJ-DGVM (Sitch et al., 2003), is a process-based model to simulate global vegetation dynamics and the associated carbon and water fluxes on 30 arc-min grid cells. Agricultural land-use productivity is simulated through the consideration of crop functional types (CFTs), either rain-fed or irrigated, representing the world's most important annual field crops. Moreover, LPJmL's crop module simulates sowing dates, crop phenology, crop growth and carbon allocation at a daily time step. All four processes respond to climate variables such as precipitation, temperature and insolation. The input data differentiates between nine soil texture classes as described by Sitch et al. (2003). Soil water storage is considered in two layers up to $1.5 \mathrm{~m}$ deep $(0.5 \mathrm{~m}$ upper and $1.0 \mathrm{~m}$ lower layer). Water content is updated daily, taking into account snowmelt, percolation, rainfall, evapotranspiration, runoff and interception (Sitch et al., 2003; Gerten et al., 2004). A comprehensive evaluation of LPJmL's performance for the simulation of crop yields, crop phenology and carbon-fluxes is presented in Bondeau et al. (2007).

For our assessment, the model is applied to calculate irrigated crop yields and irrigation water requirement surfaces for maize, i.e. simulation runs for that specific CFT are performed for all grid cells within our study region. The model is run for the period 1901-2003, preceded by a 1000-year spin-up phase in order to bring carbon pools into equilibrium. For this run, we use CRU-TS2.1 climate data on monthly mean temperature, precipitation, number of wet days and cloud cover (Österle et al., 2003; Mitchell and Jones, 2005). Annual atmospheric $\mathrm{CO}_{2}$ concentration is taken from Keeling and Whorf (2005) and Sitch et al. (2003). Based on the model output, mean yields per ha and mean irrigation water requirements for the period 1991-2000 are calculated. In order to derive silage maize yields (use of the whole plant), we assume a corn fraction of $40 \%$ and a dry mass content in the whole plant of $30 \%$ (KTBL, 2005).

Irrigation water requirements for maize are determined from the soil water deficit below optimal growth of that CFT, i.e. the soil water needed in order to avoid any plant water stress. Plant water stress is calculated as the ratio between plant canopy water supply and atmospheric demand for transpiration.

\subsection{Spatial analysis}

First step of the spatial analysis is the selection of irrigated cropland cells with calculated silage maize yields higher than a threshold value above that cultivation becomes profitable. Since our assessment focuses on highly productive agricultural land, we assume this threshold at $100 \mathrm{dtdm}$ irrigated silage maize yield per ha. For the irrigated cropland cells meeting this target, a multi-criteria analysis (MCA) is 
conducted to determine their suitability for silage maize cultivation. The suitability value $\Psi_{k}$ of grid cell $k$ is expressed by Eq. (1).

$\Psi_{k}=\frac{f\left(\text { myield }_{k}\right)+g\left(\mathrm{iwr}_{k}\right)}{2}$

Two equally important factors contribute to the cell's suitability: irrigated silage maize yield (myield) and irrigation water requirements (iwr).

$$
\begin{aligned}
& f\left(\text { myield }_{k}\right)=\left(\frac{\text { myield }_{k}-\text { min myield }}{\text { max myield }- \text { min myield }}\right) \\
& g\left(\text { iwr }_{k}\right)=1-\left(\frac{\text { iwr }_{k}-\text { min iwr }}{\text { max iwr }- \text { min iwr }}\right)
\end{aligned}
$$

Both factors are standardized by the value functions $f$ and $g$, which have a co-domain from 0 to 1 (Geneletti et al., 2005). For crop yield, a positive linear function is used (Eq. 2), leading to higher factor values for higher yields, while for iwr a negative linear relationship is assumed, meaning that higher irrigation water requirements have an increasingly negative influence on the cell's suitability value (Eq. 3). The functions are scaled between the maximum and minimum factor values found in the set of the selected irrigated cropland cells. In case of maize yield the minimum factor value is given by the lower threshold of $100 \mathrm{dt} \mathrm{dm}$. The analysis was carried out with the ArcGIS software using Map Algebra operations.

\subsection{Performance indicators}

The total production of silage maize in metric tons and the irrigation water requirements in $\mathrm{m}^{3}$ for each irrigated cropland grid cell are determined by multiplying the simulated yield per ha and irrigation water requirements with the extent of area equipped for irrigation located there. Regarding the amount of energy that can be produced from silage maize, we assume that $1 \mathrm{t}$ fresh mass $(=0.3 \mathrm{tdm})$ yields $200 \mathrm{~m}^{3}$ of biogas with a methane content of 52\% and a lower heating value of $21.6 \mathrm{MJ} / \mathrm{m}^{3}$ (FNR, 2008).

Then, the suitable irrigated cropland area is subdivided into ten groups, each representing a decile of the total area sum. Group 1 contains the cells with the most suitable $10 \%$ of irrigated cropland area on them while group 10 contains the cells with the $10 \%$ of irrigated cropland area having the lowest suitability values. For each group, first its Energy productivity $E[\mathrm{PJ}]$ is determined, which is defined as the sum of energy that can be produced on the irrigated area within that group. Based on this information for each group the efficiency of using irrigation water and land area for the production of bio-energy is evaluated.

For this purpose, we have developed two performance indicators (Eq. 4): (1) Water Intensity WI $\left[\mathrm{km}^{3} / \mathrm{PJ}\right]$ describes the mean volume of irrigation water consumed per energy

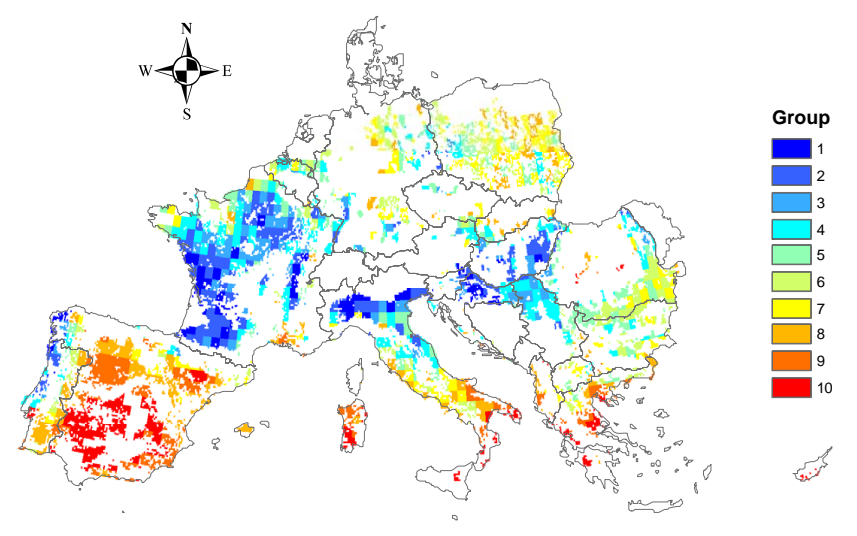

Fig. 2. Spatial distribution of suitable irrigated cropland in decile groups. For the EU27 member states in Scandinavia and the UK, no suitable irrigated cropland area has been identified due to the applied yield threshold.

unit and (2) Area Intensity AI $\left[\mathrm{km}^{2} / \mathrm{PJ}\right]$ specifies the mean area of land needed per energy unit.

$$
\begin{aligned}
& \mathrm{WI}=\frac{\mathrm{iwr}}{E}\left[\mathrm{~km}^{3} / \mathrm{PJ}\right] \\
& \mathrm{AI}=\frac{\text { Area }}{E}\left[\mathrm{~km}^{2} / \mathrm{PJ}\right]
\end{aligned}
$$

\section{Results}

\subsection{Location of suitable areas to grow silage maize}

The decile grouping is based on the combined evaluation of silage maize yield and irrigation water requirements. Altogether $128000 \mathrm{~km}^{2}$ of irrigated cropland located on grid cells with silage maize yields higher than the threshold of $100 \mathrm{dtdm}$ were identified within the study region. The geographical distribution of the suitable cells within the ten groups is shown in Fig. 2. Most of the best evaluated area is located in France, Portugal, the Po-Valley in Italy and the Balkan countries Croatia, Hungary and Serbia. In the majority of Spain and the southern parts of Italy, we find relatively bad growing conditions, together with high irrigation water requirements. In the Benelux countries, Germany and Poland, yield levels are lower compared to the best evaluated cells but go together with relatively low irrigation water requirements. Also a West-East gradient with decreasing suitability values can be identified. High silage maize yield levels but also high irrigation water requirements are found in Romania and Bulgaria.

\subsection{Calculated yields and irrigation water requirements}

Comparing the characteristics of the 10 groups, we find a decline of the mean silage maize yield value (myield) from $154 \mathrm{dt}$ in group 1 (containing the most suitable cells) down 
to $106 \mathrm{dt}$ in the group 10 (containing the least suitable cells). Maximum calculated silage maize yields are $165 \mathrm{dt} \mathrm{dm}$ while the lower limit is defined by the yield threshold of $100 \mathrm{dt} \mathrm{dm}$. Irrigated cropland cells with the highest yields (here defined as values greater than the mean yield of group 1) are located at the Atlantic coast of north-western Portugal and Spain, in the region near Bordeaux in France, the Po-Valley in Italy as well as in Croatia, Romania and Bulgaria. The lowest maize yields within the scope of our analysis are found in the southern parts of Europe, among them in Spain and Greece, and in the north-eastern parts of Germany and Poland.

The medium values for irrigation water requirements (iwr) show only small differences between the first 6 groups (ranging from $541 \mathrm{~mm}$ to $550 \mathrm{~mm}$ ). Then, there is a steep incline to $620 \mathrm{~mm}$ in group 7, increasing up to more than $829 \mathrm{~mm}$ in group 10. The highest calculated iwr is $1123 \mathrm{~mm}$ for grid cells located in the southern parts of Spain and Portugal, while the lowest iwr is $94 \mathrm{~mm}$ for grid cells in Poland. In general, regions with high irrigation water requirements are located in the central and southern parts of Spain, Portugal and Italy as well as in the eastern parts of Hungary, Romania and Bulgaria. The areas with the lowest irrigation water requirements can be found in the central part of France, in Germany and in Poland.

\subsection{Plausibility of calculated yields and irrigation water requirements}

Maize yields calculated by LPJmL have been tested with good results against FAO census data for selected European countries (Bondeau et al., 2007). Nevertheless, the timeframe of that analysis was 1991-1995, meaning that yield improvements since then are not captured by the tested model version. Therefore, it can be assumed that current yields are underestimated. It also has to be noted that the testing procedure referred to corn maize. Our estimates of silage maize yields are solely based on literature data on harvest index and dry mass content. In Germany, the maximum calculated silage maize yield is $13.5 \mathrm{tdm} / \mathrm{ha}$, equalling $45 \mathrm{t} / \mathrm{ha}$ of fresh biomass. This data compares well to data from FNR (2008) and Thyø and Wenzel (2007) who also assume $45 \mathrm{t}$ of fresh mass yield in their balance calculations.

The hydrological processes within LPJmL including evapotranspiration have extensively been tested and validated by Gerten et al. (2004). Furthermore, Rost et al. (2008) successfully applied the model to analyse the global consumption of irrigation water. Total irrigation water requirements in our calculations amount to $88.52 \mathrm{~km}^{3}$, which is within the range of the values presented in Rost et al. (2008) for Europe ( 40$110 \mathrm{~km}^{3}$ ). Although these numbers are difficult to compare as our study calculates water requirements of maize which may vary from the requirements of the crops that are actually grown on the irrigated areas, the simulation results are in a reasonable order of magnitude.

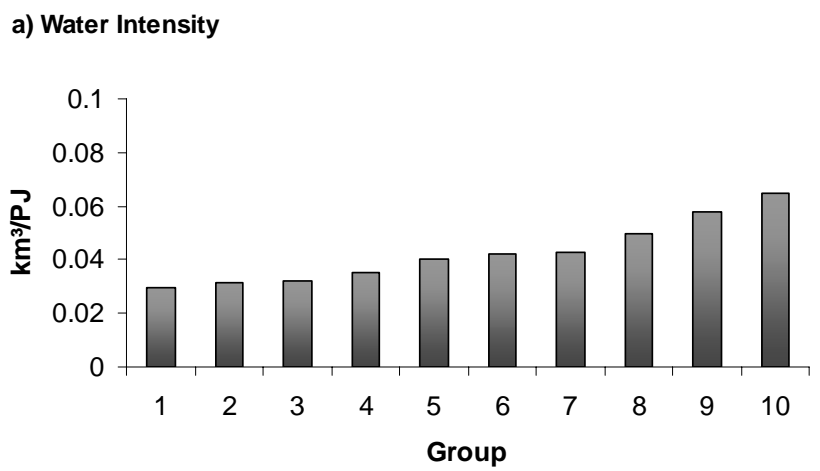

b) Area Intensity

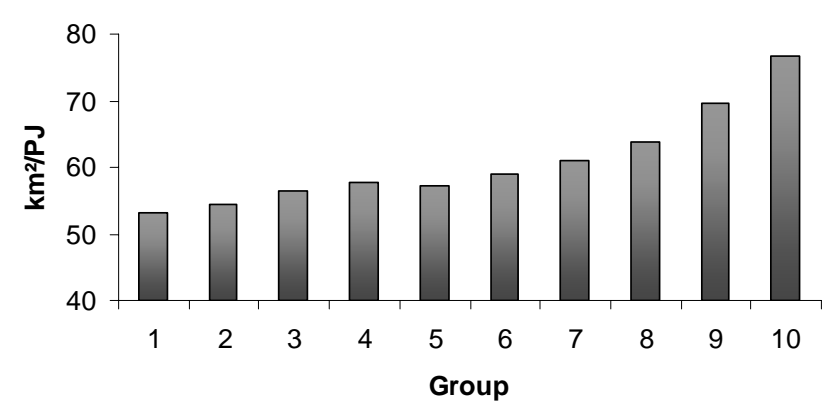

Fig. 3. Group values for the indicators (a) Water Intensity and (b) Area Intensity.

\subsection{Indicator results}

The results for the indicators Water Intensity (WI) and Area Intensity (AI) are pictured in Fig. 3. In case that all the irrigated cropland would be used simultaneously for growing silage maize, biogas with an energy content of 2136 PJ could be produced.

The total energy productivity $\mathrm{E}$ within each of the 10 groups is declining from $241.6 \mathrm{PJ}$ in group 1 to $167.5 \mathrm{PJ}$ in group 10. This trend goes along with decreasing medium silage maize yields and increasing irrigation water requirements. As a result, Water Intensity (WI) increases from $0.03 \mathrm{~km}^{3} / \mathrm{PJ}$ in group 1 , to $0.065 \mathrm{~km}^{3} / \mathrm{PJ}$ in group 10 , i.e. the amount of irrigation water that is needed to produce one PJ of energy more than doubles in group 10 compared to group 1. Also the indicator Area Intensity (AI) is increasing from $53 \mathrm{~km}^{2} / \mathrm{PJ}$ in group 1 to $76.78 \mathrm{~km}^{2} / \mathrm{PJ}$ in group 10 , meaning that more cropland area is needed to produce the same amount of energy in the groups with lower suitability values.

\section{Discussion and conclusions}

The study provides the first assessment of the potentials of European irrigated cropland for the production of biogas as one important bio-energy option. Within a GIS environment the output of a process-based vegetation model was 
combined with other data sources to conduct a spatially explicit analysis. We decided to use the LPJmL model because it is designed for large-scale grid-based applications and its capabilities to simulate crop yields and crop water balance are well tested (Bondeau et al., 2007; Rost et al., 2008). Furthermore its process-based structure allows simulating the effects of changing climate conditions in future studies.

Major limitations of the proposed methodology are the differences of the spatial resolution of the input data and the presently realized parameterization and application procedure of the vegetation model. While the outcome of the LPJmL simulations is provided on a 30 arc-min grid, the spatial analysis is conducted on a finer 5 arc-min scale level. Thus, the application of the model on smaller grid cells would greatly enhance the spatial variability of the study results. Moreover, the silage maize yields are derived from corn maize yields. Improvements of the study design should therefore also include the parameterization of a new crop functional type for silage maize. Furthermore, model runs were summarized for the time period 1991-2000. The effect of inter-annual variability of climate variables such as temperature and precipitation on irrigation water requirements and crop yields (Alcamo et al., 2007) is not taken into account. Here, additional testing of the model's capability to capture such dynamics will be necessary.

The findings of our analysis indicate that the existing area equipped for irrigation can contribute significantly to the production of biogas. Assuming that silage maize is part of a 3-year crop rotation, the amount of bio-energy that can be produced on the total analysed area amounts to $712 \mathrm{PJ}$ per year, which is about $11 \%$ of the EU target for the share of renewable energy sources at the total primary energy consumption in the year 2010 (EC, 2005). The grouped indicator results also reveal large spatial differences in the performance of silage maize production in respect of irrigation water use and area requirements.

We regard both aspects that are covered by our indicators as central elements for the planning of sustainable bioenergy systems. On the one hand, higher irrigation water requirements can directly affect local water resources as well as the greenhouse gas balance of bio-energy crops by using additional energy for pumping and water distribution. On the other hand, land requirements for energy cropping are in competition with crop cultivation for food production. Therefore, the presented methodology can become a tool to help stimulating policy discussion about strategies for the use also of irrigated land for bio-energy cropping and ultimately to identify suitable regions in Europe where biogas development should be promoted. In this context, the results can serve as input to further analysis of the water footprint (Gerbens-Leenens et al., 2008) and the energy balance of bio-energy systems within comprehensive life-cycle analysis. Since we use global data sets and apply a global vegetation model which is capable to simulate a multitude of different crop types, the presented type of assessment can be transferred to other world regions and expanded to other crop types that are relevant for bio-energy production.

Another simplification of our current model approach is the assumption that irrigation water requirements can always be met, leading to optimal crop growth. In reality, limited or decreasing water availability can result in a lower supply of irrigation water and consequently lower crop yields. Therefore, our future work will expand the study design to a more integrated scenario analysis, considering climate change and its effects on water availability as well as the competition for water resources between agriculture, households and industry. The refinement of the suitability assessment will introduce a spatial link to infrastructural aspects, including transportation logistics and the location of biogas plants. Furthermore, a more sophisticated economic approach to determine the yield threshold and the economically feasible amount of applied irrigation water will be integrated.

Acknowledgements. The work has been conducted as part of the EU SCENES project. The authors thank their colleagues at the Climate Impacts and Vulnerabilities group at the Potsdam Institute for Climate Impact Research (PIK) for providing access to the LPJmL model.

Edited by: B. Schmalz, K. Bieger, and N. Fohrer

Reviewed by: R. Ludwig and another anonymous referee

\section{References}

Alcamo, J., Dronin, N., Endejan, M., Golubev, G., and Kirilenko, A.: A new assessment of climate change impacts on food production shortfalls and water availability in Russia, Global Environ. Change, 17(3-4), 429-444, 2007.

Bondeau, A., Smith, P. C., Zaehle, S., Schaphoff, S., Lucht, W., Cramer, W., Gerten, D., Lotze-Campen, H., Müller, C., Reichstein, M., and Smith, B.: Modelling the role of agriculture for the 20th century global terrestrial carbon balance, Global Change Biol., 13, 679-706, 2007.

EC, European Commission: Communication from the European Commission on the Biomass Action Plan, COM(2005)628 final, 2005.

EC, European Commission: Communication from the Commission to the Council and the European Parliament: Renewable Energy Road Map Renewable energies in the 21st century: building a more sustainable future, $\operatorname{COM}(2006) 848$ final, 2006.

EEA, European Environment Agency: How much bio-energy can Europe produce without harming the environment? EEA Report No. 07/2006, 2006.

EEA, European Environment Agency: Corine Land Cover 2000 dataset (CLC2000), http://dataservice.eea.europa.eu/dataservice/ metadetails.asp?id=1007, 2007.

Fargione, J., Hill, J., Tilman, D., Polasky, S., and Hawthorne, P.: Land clearing and the biofuel carbon debt, Science, 319(5867), 1235-1238, 2008.

FNR, Fachagentur für Nachwachsende Rohstoffe e.V.: Biogas Basisdaten Deutschland, 2008. 
Geneletti D.: A GIS-based decision support system to identify nature conservation priorities in an alpine valley, Land Use Pol., 21, $149-160,2005$.

Gerbens-Leenens, P. W., Hoekstra, A. Y., Van der Meer, T. H.: Water footprint of bio-energy and other primary energy carriers, Value of water reaearch report series, No. 29, Unesco-IHE, Institute for Water Education, 2008.

Gerten, D., Schaphoff, S., Haberlandt, U., Lucht, W., and Sitch, S.: Terrestrial vegetation and water balance-hydrological evaluation of a dynamic global vegetation model, J. Hydrol., 286, 249-270, 2004.

Heistermann, M.: Modelling the Global Dynamics of Rain-fed and Irrigated Croplands, Reports on Earth System Science, Max Planck-Institute for Meteorology Hamburg, Germany, 2006.

Hoogwijk, M., Faaij, A., Eickhout, B., de Vries, B., and Turkenburg, W.: Potential of biomass energy out to 2100, for four IPCC SRES land-use scenarios, Biomass and Bioenergy, 29, 225-227, 2005.

Keeling, C. and Whorf, T.: Atmospheric $\mathrm{CO}_{2}$ records from sites in the SIO air sampling network, in Trends: A Compendium of Data on Global Change, Carbon Dioxide Information Analysis Center, Oak Ridge National Laboratory, Oak Ridge, TN, USA, 2005.

KTBL, Kuratorium für Technik und Bauwesen in der Landwirtschaft e.V.: Faustzahlen für die Landwirtschaft, 13. Auflage, 2005.

Mitchell, T. D. and Jones P. D.: An improved method of constructing a database of monthly climate observations and associated high resolution grids, Int. J. Climatol., 25(6), 693-712, doi:10.1002/joc.1181, 2005.
Österle, H., Gerstengarbe, F. W., and Werner P. C.: Homogenisierung und Aktualisierung des Klimadatensatzes der Climate Research Unit der Universität of East Anglia, Norwich, Terra Nostra, 6, Deutsche Klimatagung, Potsdam, Germany, 2003.

Rost, S., Gerten, D., Bondeau, A., Luncht, W., Rohwer, J., and Schaphoff, S.: Agricultural green and blue water consumption and its influence on the global water system, Water Resour. Res., 44, W09405, doi:10.1029/2007WR006331, 2008.

Searchinger, T., Heimlich, R., Houghton, R. A., Dong, F., Elobeid, A., Fabiosa, J., Tokgoz, S., Hayes, D., and Yu, T.: Use of U.S Croplands for Biofuels Increases Greenhouse Gases Through Emissions from Land-Use Change, Science, 319(5867), 2381240, 2008.

Siebert, S., Döll, P., Feick, S., Frenken, K., and Hogeveen, J.: Global map of irrigated areas version 4.0.1, University of Frankfurt, Germany / Food and Agriculture Organisation of the UN, Rome, Italy, 2007.

Sitch, S., Smith B., Prentice, I. C., Arneth, A., Bondeau, A., Cramer, W., Kaplans, J. O., Levis, S., Lucht, W., Sykes, M. T., Thonicke, K., and Venevsky, S.: Evaluation of ecosystem dynamics, plant geography and terrestrial carbon cycling in the LPJ dynamic global vegetation model, Global Change Biol., 9, 161185, 2003.

Thyø, K. A. and Wenzel, H: Life Cycle Assessment of Biogas from Maize silage and from Manure : for transport and for heat and power production under displacement of natural gas based heat works and marginal electricity in northern Germany, Lyngby, Denmark, Institute for Product Development, 86 pp., Report, 2007 